\title{
Vertical profiles of cobalt and zinc in marine sediments of the Santa Rosalía mining region, Gulf of California, Mexico
}

\author{
Perfiles verticales del cobalto y zinc en los sedimentos marinos de la \\ región minera de Santa Rosalía, Golfo de California, México
}

\author{
E. Shumilin, G. Rodríguez Figueroa ${ }^{1}$, D. Sapozhnikov², N. Mirlean ${ }^{3}$ \\ ${ }^{1}$ Centro Interdisciplinario de Ciencias Marinas-Instituto Politécnico Nacional, Av. IPN s/n, colonia Playa \\ Palo de Santa Rita, Apdo. postal 592, La Paz, Baja California Sur, 23096, Mexico. \\ eshumili@gmail.com; griselmarg@gmail.com \\ ${ }^{2}$ V.I. Vernadsky Institute of Geochemistry and Analytical Chemistry, Russian Academy of Sciences, Moscow, Russia. \\ sapozh@mail.ru \\ ${ }^{3}$ Oceanography Geological Laboratory, Oceanography Institute, Federal University of Rio Grande, Brazil. \\ dgeonmir@furg.br
}

Corresponding author: eshumili@gmail.com

Received: 29/04/2011 / Accepted: 12/04/2013

\begin{abstract}
Core sediments that were sampled from the coastal zone of the Santa Rosalía mining region and the adjacent deeper area of the Gulf of California were analysed by an instrumental neutron activation analysis (INAA). The levels of $\mathrm{Co}$, Sc and $\mathrm{Zn}$ were used to assess the effect of pollution from the solid wastes of a copper smelter on the sediment composition in the study area. The Co/Sc and $\mathrm{Zn} / \mathrm{Sc}$ ratio vertical distributions were compared to $\mathrm{Co} / \mathrm{Sc}$ and $\mathrm{Zn} / \mathrm{Sc}$ ratios of the earth's crust and to a lower layer of the sediment cores and therefore less affected by pollution. The ratios of $\mathrm{Co} / \mathrm{Sc}$ and $\mathrm{Zn} / \mathrm{Sc}$ in cores from a predominant pollution "hot spot" near Santa Rosalía port are very high (40-150 and 150-350, respectively), suggesting that the thickness of the polluted layer exceeded the length of the cores $(75-93 \mathrm{~cm})$. The values of $\mathrm{Co} / \mathrm{Sc}$ and $\mathrm{Zn} / \mathrm{Sc}$ ratios decrease drastically in the cores collected outside the main "hot spot". In this case, the values obtained from core depths of 20-34 cm approached the regional coastal surface sediment background (approximately 2 and 5-10 for $\mathrm{Co} / \mathrm{Sc}$ and $\mathrm{Zn} / \mathrm{Sc}$, respectivelly). The $\mathrm{Co} / \mathrm{Sc}$ ratios for the sediments of the deeper and further from the coast cores are slightly variable, but at sediment depths below $15 \mathrm{~cm}$ they are nearly constant and approximately equal to the $\mathrm{Co} /$ Sc ratio of the earth's crust. In the upper part of these cores $(0-15 \mathrm{~cm})$, the $\mathrm{Zn} / \mathrm{Sc}$ ratios are higher $(10-20)$ than the $\mathrm{Zn} / \mathrm{Sc}$ ratio of the earth's crust, which was probably due to the additional input of incompletely mineralised biogenic particulate $\mathrm{Zn}$ from the photic layer of the water column. The shape of the vertical profile the $\mathrm{Zn} / \mathrm{Sc}$ ratio of SR22 sediment core (depth $360 \mathrm{~m}$ ) in front of the main pollution "hot spot" shows that the maximum levels of pollution occurred in the past, and self-purification/restoration of the natural pollutant levels in the fine deep-water sediments can be observed during recent years.
\end{abstract}

Keywords: cobalt, zinc, pollution, marine sediments, Santa Rosalía mining region, Baja California peninsula, Mexico

Resumen

Los sedimentos de los testigos muestreados en la zona costera de la región minera de Santa Rosalía y en el área adyacente más profunda del Golfo de California se analizaron con el análisis instrumental de la activación neutrónica (AIAN). Los niveles de Co, Sc y Zn se usaron para evaluar el efecto de la polución producida por los desechos sólidos de la fundidora de cobre sobre los sedimentos del área de estudio. Las distribuciones verticales de las relaciones $\mathrm{Co} / \mathrm{Sc}$ y $\mathrm{Zn} / \mathrm{Sc}$ se compararon con las relaciones $\mathrm{Co} / \mathrm{Sc}$ y 
$\mathrm{Zn} / \mathrm{Sc}$ de la corteza terrestre y con las obtenidas en la capa inferior de los testigos de sedimentos menos afectados por la polución. Las relaciones de $\mathrm{Co} / \mathrm{Sc}$ and $\mathrm{Zn} / \mathrm{Sc}$ en los testigos de sedimentos del área con mayor polución cerca del puerto de Santa Rosalía son muy altas, oscilando desde 40 hasta 150 y de 150 hasta 350 respectivamente, sugiriendo que el espesor de la capa altamente contaminada excede la longitud de los testigos $(75-93 \mathrm{~cm})$. Los valores de las relaciones $\mathrm{Co} / \mathrm{Sc}$ y Zn/Sc disminuyen drásticamente en los testigos muestreados fuera de la principal área de polución. En este caso, los valores obtenidos en la profundidad de 20-34 cm del testigo se aproximan a los valores regionales de fondo de las relaciones para los sedimentos superficiales costeros (cerca a 2 para $\mathrm{Co} / \mathrm{Sc}$ y a 5-10 para $\mathrm{Zn} / \mathrm{Sc}$ ). Las relaciones $\mathrm{Co} / \mathrm{Sc}$ para los sedimentos de los testigos, muestreados a mayor profundidad y distancia de la costa son ligeramente variables, pero por debajo de $15 \mathrm{~cm}$ son casi constantes y aproximadamente iguales a la relación de $\mathrm{Co} / \mathrm{Sc}$ para la corteza terrestre. En la parte superior $(0-15 \mathrm{~cm})$ de estos testigos de sedimentos, las relaciones $\mathrm{Zn} / \mathrm{Sc}$ son más altas (10-20) que las relaciones $\mathrm{Zn} / \mathrm{Sc}$ para la corteza terrestre, debido, probablemente, al aporte adicional del Zn biogénico particulado desde la capa fótica de la columna del agua. La forma del perfil vertical de las relaciones $\mathrm{Zn} / \mathrm{Sc}$ del testigo de sedimentos SR22 (360 m de profundidad) frente al área de mayor polución muestra que los niveles máximos de polución ocurrieron en el pasado, y una autopurificación/restauración de los niveles naturales de los contaminantes en los sedimentos finos profundos se puede observar durante los últimos años.

Palabras clave: cobalto, zinc, contaminación, sedimentos marinos, región minera de Santa Rosalía, península de Baja California, México

\section{Introduction}

The metal mining and smelting on the sea shore is quite common because of the close proximity of mineral deposits to the tectonically active areas of land-sea interfaces where ancient hydrothermal vents have been uplifted and exposed on the continental margins. The most well-known cases include copper deposits and mines along the Pacific coast of Canada (e.g., the "Brittania" mine in British Columbia), along the coast of northern Chile (near Antofagasta) and in West Greenland (Elberling et al., 2002), in addition to a $\mathrm{Pb}$ smelter in the East of Russia on the shore of the Sea of Japan (i.e., near Dalnegorsk in the Primorye region) (Shulkin, 1998). The dumping of mining tailings and solid smelting wastes into the adjacent sea used to be a widespread practice in the past.

One of these sites where sediments are strongly contaminated is a coastal zone along the Santa Rosalía mining region on the eastern shore in the centre of the
Baja California peninsula in Mexico (Fig. 1). This area displays high levels of metals that are associated with former copper mining and smelting activities that were performed for nearly a century (Wilson and Rocha, 1955; Rodríguez Figueroa, 2004). There is clear evidence of the pollution of surface sediments by such solid waste dumping (Shumilin et al., 2000; Rodríguez Figueroa, 2004, 2010); however, recent data were somewhat encouraging, as the heavy metals from highly polluted sites were shown to be mainly concentrated in the residual fraction of the surface sediments (Shumilin et al., 2011). Additionally, an analysis of the metal levels in brown seaweeds showed that most toxic metals were retained in the sediments and were not released to the water column (Choumiline et al., 2006; Rodríguez Figueroa, 2010; Rodríguez-Figueroa et al., 2010). However, various severe environmental problems are still very real. For example, while the mining and smelting activities in Santa Rosalía closed more than twenty years ago, the self-cleaning/restoration dynamics of the pollution "hot spot" have not

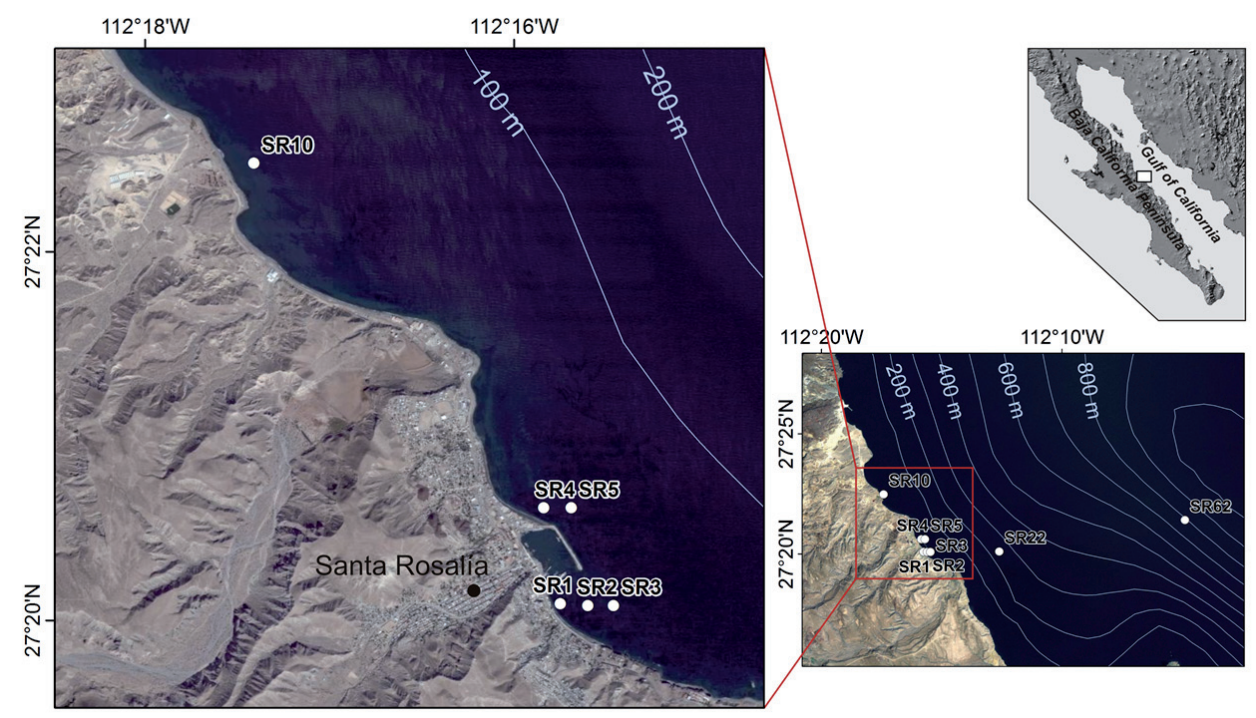

Fig. 1.- Study area and locations of the sampling sites for sediment cores in the coastal zone of the Santa Rosalía copper mining region in the Gulf of California.

Fig. 1.- Área de estudio y localización de los sitios de muestreo de los testigos de sedimentos en la zona costera de la región minera cuprífera de Santa Rosalía en el Golfo de California. 
yet been characterised.

Cobalt and zinc are environmentally important trace metals (Smith and Carson, 1981). The concept of geochemical provinces has been considered in relation to their regional availability and their transfer through the food chain to humans (Hamilton, 1994). Both cobalt and zinc are essential micronutrients for marine phytoplankton growth. They are supplied to the ocean mainly through estuarine systems from land (Tovar-Sánchez et al., 2004). Interestingly, these two elements can replace one another metabolically in marine phytoplankton that has been cultivated under laboratory conditions (Sunda and Huntsman, 1995). Co and, to a lesser extent, Zn are significantly enriched in the marine sediments of the Gulf of Iskenderen (Turkey) relative to their average crustal abundance. This enrichment is mainly due to the input of the weathered products of basic and ultrabasic source rocks that are present on the adjacent coast and hinterland (Ergin et al., 1996). Sometimes, Co and $\mathrm{Zn}$ are greatly enriched in the environment, for example, in fjord sediments near a former mine in West Greenland (Elberling et al., 2002) or in the "Boleo" copper mining district on the eastern coast of the Baja California peninsula, near the town of Santa Rosalía (Wilson and Rocha, 1955; Shumilin et al., 2000; Rodríguez Figueroa, 2004).

Because of natural $\mathrm{Cu}-\mathrm{Co}-\mathrm{Zn}$ mineralization, the Santa Rosalía mining region was extensively used for copper mining and smelting throughout the past century. As a result, local beach sands and coastal marine sediments are strongly contaminated by $\mathrm{Cu}, \mathrm{Co}, \mathrm{Zn}$ and other heavy metals (Shumilin et al., 2000; 2005). However, the impacted zones and the penetration depth into the sedimentary column are ostensibly limited in size (Rodríguez Figueroa, 2010; Rodríguez et al., 1998; Shumilin et al., 2000a, 2000b).

The objective of this study was to determine the vertical distribution of the anthropogenic contaminants at certain sites that were selected within the impacted area and a supposedly unaffected zone of the adjacent part of the Gulf of California to determine the depth at which the sedimentary column is affected by the pollution and to discover any evidence of self-cleaning processes. Our previous studies of smelting wastes, arroyo sediments, beach sands and surface marine sediments showed that there is a significant presence of $\mathrm{Cu}, \mathrm{Co}, \mathrm{Mn}$ and $\mathrm{Zn}$ in contaminated sedimentary materials. However, Co and $\mathrm{Zn}$ are especially convenient elements for accomplishing this type of environmental assessment because instrumental neutron activation analysis (INAA) for these elements is a very effective tool to analyse a considerable quantity of subsamples rapidly and inexpensively. Other contaminants, such as $\mathrm{Cu}$ and $\mathrm{Mn}$, cannot be measured

\begin{tabular}{ccccc}
\hline Element & $\begin{array}{c}\text { Median } \\
\text { certified value } \\
\left(\mathbf{m g ~ k g}^{-1}\right)\end{array}$ & $\begin{array}{c}\text { Certified } \\
\text { range } \\
\left(\mathbf{m g ~ k g}^{-1}\right)\end{array}$ & $\begin{array}{c}\text { Measured } \\
\text { concentration } \\
\left(\mathbf{m g ~ k g}^{-1}\right)\end{array}$ & $\begin{array}{c}\text { Accuracy } \\
\mathbf{( \% )}\end{array}$ \\
\hline Cobalt & 15.0 & $14.1-16.4$ & $14.7 \pm 0.7$ & 2.0 \\
Scandium & 6.90 & $6.75-9.99$ & $7.10 \pm 0.15$ & 2.9 \\
Zinc & 977 & $936-1019$ & $1170 \pm 79$ & 19.8 \\
\hline
\end{tabular}

Table 1.- Accuracy information (\%) of $\mathrm{Co}, \mathrm{Sc}$ and $\mathrm{Zn}$ determinations in the certified reference material "IAEA-356" (polluted marine sediment).

Tabla 1.- Información sobre la exactitud de las determinaciones de Co, $\mathrm{Sc}$ y $\mathrm{Zn}$ en el material de referencia estándar certificado "IAEA-356" (sedimento marino contaminado).

by the traditional INAA technique and require a laborious strong acid digestion to obtain solutions that can finally be measured by flame atomic absorption spectrophotometry or ICP-AES. Moreover, there have been some indications that the complete digestion of materials originating from a smelter in Santa Rosalía is difficult to achieve (Rodríguez Figueroa, 2010). To minimise any possible effects of grain size and dilution by biogenic calcium carbonate or biogenic silica on the levels of $\mathrm{Co}$ and $\mathrm{Zn}$ in the sediments, the normalisation of their absolute values with scandium was applied (Dias and Prudêncio, 1998; Grousset et al., 1995; Monna et al., 2004). Scandium belongs to a group of terrigenous indicators (i.e., $\mathrm{Al}, \mathrm{Cs}, \mathrm{Ti}, \mathrm{Li}, \mathrm{Sc}$ and $\mathrm{Th}$ ) that are strongly associated with aluminosilicates in soils and sediments, and it was selected for our study because it is the only element of this group that can easily be measured by INAA in a solid matrix with high precision. Moreover, the linear regressions of the levels of many elements versus the levels of Sc in the sedimentary materials from the coastal environments of southern Baja California have displayed the best correlation coefficients when compared with $\mathrm{Al}$, Ti or Fe (Rodríguez Castañeda, 2008). The $\mathrm{Co} / \mathrm{Sc}$ and $\mathrm{Zn} / \mathrm{Sc}$ ratio vertical profiles were prepared and taken into consideration to assess the depth of penetration of the contaminants into the marine sediments.

\section{Materials and methods}

\subsection{Sampling}

The study area and the locations of the sampling stations are shown in Figure 1. The SR1-SR-5 and SR-10 sediment core samples were collected in April 2006 using a manual corer (length $100 \mathrm{~cm}$ ) by scuba divers from a small plastic motorboat that was used as a platform for separating the core sediment samples.

The coastal core samples were thoroughly extracted from the core and, depending on the results of visual ob- 


\begin{tabular}{cccc}
\hline $\begin{array}{c}\text { Sediment } \\
\text { depth, cm }\end{array}$ & $\begin{array}{c}\text { Cobalt } \\
\text { (Co) }\end{array}$ & $\begin{array}{c}\text { Scandium } \\
\text { (Sc) }\end{array}$ & Zinc (Zn) \\
\hline \multicolumn{4}{c}{ Core SR1 } \\
$0-2$ & 1037 & 7.26 & 2475 \\
$2-4$ & 1218 & 11.1 & 3780 \\
$4-6$ & 1079 & 10.8 & 2180 \\
$6-10$ & 930 & 9.46 & 2360 \\
$10-15$ & 995 & 9.40 & 2820 \\
$15-20$ & 1103 & 9.69 & 2650 \\
$20-25$ & 1097 & 9.48 & 2440 \\
$25-30$ & 1232 & 9.32 & 2720 \\
$30-40$ & 1193 & 9.09 & 3100 \\
$40-50$ & 1084 & 10.3 & 2800 \\
$50-60$ & 1060 & 10.5 & 2850 \\
$60-70$ & 1131 & 7.48 & 2470 \\
$70-80$ & 968 & 9.41 & 2340 \\
$80-86$ & 1103 & 11.4 & 2880 \\
$86-91$ & 790 & 10.2 & 1720 \\
& Core SR2 & & \\
$0-5$ & 764 & 9.9 & 2385 \\
$5-10$ & 806 & 11.2 & 1820 \\
$10-15$ & 951 & 12.5 & 2350 \\
$15-20$ & 945 & 11.1 & 2650 \\
$20-25$ & 885 & 10.8 & 2110 \\
$25-30$ & 1006 & 11.4 & 3110 \\
$30-35$ & 738 & 8.46 & 2440 \\
$35-40$ & 1028 & 10.0 & 3150 \\
$40-50$ & 743 & 8.68 & 2520 \\
$50-60$ & 921 & 10.1 & 3230 \\
$60-70$ & 901 & 10.4 & 3140 \\
$70-78$ & 1242 & 10.9 & 3040 \\
& Core SR 3 & & \\
$0-5$ & 45.5 & 13.0 & 210 \\
$5-10$ & 45.8 & 15.0 & 180 \\
$10-15$ & 45.7 & 16.6 & 140 \\
$15-20$ & 45.7 & 14.2 & 190 \\
$20-30$ & 65.9 & 14.5 & 430 \\
$30-40$ & 28.8 & 14.6 & 40 \\
$40-50$ & 21.9 & 13.9 & 30 \\
$50-60$ & 22.9 & 13.2 & 10 \\
$60-70$ & 20.6 & 14.6 & 90 \\
$70-77$ & 32.3 & 16.0 & 150 \\
\hline & & &
\end{tabular}

\begin{tabular}{|c|c|c|c|}
\hline $\begin{array}{l}\text { Sediment } \\
\text { depth, cm }\end{array}$ & $\begin{array}{l}\text { Cobalt } \\
\text { (Co) }\end{array}$ & $\begin{array}{l}\text { Scandium } \\
\text { (Sc) }\end{array}$ & Zinc (Zn) \\
\hline \multicolumn{4}{|c|}{ Core SR4 } \\
\hline $0-5$ & 771 & 11.9 & 2990 \\
\hline $5-10$ & 674 & 11.8 & 2860 \\
\hline $10-15$ & 741 & 11.7 & 3040 \\
\hline $15-20$ & 583 & 12.7 & 2250 \\
\hline $20-30$ & 548 & 11.5 & 2440 \\
\hline $30-40$ & 566 & 13.2 & 2060 \\
\hline $40-50$ & 644 & 12.4 & 2920 \\
\hline $50-60$ & 609 & 11.5 & 2880 \\
\hline $60-70$ & 688 & 11.8 & 2580 \\
\hline $70-80$ & 555 & 11.6 & 2460 \\
\hline $80-90$ & 547 & 13.0 & 2110 \\
\hline $90-96$ & 570 & 11.6 & 2220 \\
\hline \multicolumn{4}{|c|}{ Core SR 5} \\
\hline $0-2.5$ & 63 & 13.8 & 300 \\
\hline $2.5-5$ & 49.4 & 13.5 & 80 \\
\hline $5-10$ & 56.8 & 12.1 & 180 \\
\hline $10-15$ & 46.8 & 11.3 & 260 \\
\hline $15-20$ & 40.4 & 15.1 & 40 \\
\hline $20-25$ & 23.2 & 15.2 & 130 \\
\hline $25-30$ & 18.6 & 13.2 & 70 \\
\hline $30-35$ & 18.9 & 13.7 & 10 \\
\hline $35-40$ & 20.8 & 13.1 & 110 \\
\hline $40-45$ & 21.8 & 16.2 & 40 \\
\hline $45-50$ & 19.1 & 13.8 & 80 \\
\hline $50-56$ & 33.7 & 16.3 & 120 \\
\hline \multicolumn{4}{|c|}{ Core SR 10} \\
\hline $0-2.5$ & 28.5 & 13.2 & 115 \\
\hline $2.5-5$ & 27.8 & 13.6 & 120 \\
\hline $5-7.5$ & 26.6 & 14.3 & 70 \\
\hline $7.5-10$ & 25.2 & 15.2 & 150 \\
\hline $10-12.5$ & 24.8 & 14.2 & 90 \\
\hline $12.5-15$ & 36.0 & 11.0 & 340 \\
\hline $15-17.5$ & 27.9 & 13.4 & 140 \\
\hline $17.5-20$ & 28.0 & 13.0 & 150 \\
\hline $20-22.5$ & 27.5 & 13.7 & 40 \\
\hline $22.5-25$ & 37.2 & 12.1 & 250 \\
\hline $25-27.5$ & 30.0 & 13.0 & 120 \\
\hline $27.5-30$ & 18.8 & 13.9 & 80 \\
\hline $30-32.5$ & 23.9 & 14.1 & 90 \\
\hline $32.5-35$ & 16.7 & 12.1 & 120 \\
\hline $35-37.5$ & 17.5 & 13.8 & 50 \\
\hline $39-41$ & 13.8 & 15.5 & 10 \\
\hline
\end{tabular}

Table 2.- Concentrations of $\mathrm{Co}$, Sc and $\mathrm{Zn}\left(\mathrm{mg} \mathrm{kg}^{-1}\right)$ in the sediments of cores SR1 to SR5 and SR10 from the coastal zone of the Santa Rosalía mining region.

Tabla 2.- Concentraciones de $\mathrm{Co}, \mathrm{Sc}$ y $\mathrm{Zn}\left(\mathrm{mg} \mathrm{kg}^{-1}\right)$ en los sedimentos de los testigos SR1 a SR5 y SR10 de la zona costera de la región minera de Santa Rosalía.

servation of the opened core directly after sampling, were separated into layers $(1 \mathrm{~cm}, 2.5 \mathrm{~cm}$ and $5 \mathrm{~cm}$ thick) using a plastic knife and a ruler. Then, they were transferred with a plastic spoon into pre-cleaned polyethylene packets and stored in a freezer until processing. In the laboratory, the samples were thawed and split into subsamples before treatment.

Two deep-water cores, SR22 and SR62, were sampled in 1994 by a box corer in the Gulf of California in front of the Santa Rosalía port during the "El Puma" cruise (Fig. 1) and were sliced into $2 \mathrm{~cm}$ thick sediment subsamples. Related data on the composition of the sediments of SR22 and SR62 cores have been described previously (Shumilin et al., 2000a; Choumiline et al., 2006).

\subsection{Analysis}

The levels of $\mathrm{Co}, \mathrm{Sc}$ and $\mathrm{Zn}$ in the samples of finely ground and dried sediments were determined using INAA (Shumilin et al., 2000a). The samples were dried in an electrical oven at $60^{\circ} \mathrm{C}$ for $24 \mathrm{~h}$, and homogenised in an agate mortar. Then, $20 \mathrm{mg}$ subsamples, in addition to certified standard reference material IAEA-356 (polluted marine sediment), homemade Russian standard reference materials (RCC-1, SARM-7, ST, SGD, KH, RUS, TB) and the stone meteorite "Allende" were irradiated simultaneously in an experimental nuclear reactor with a flux of thermal neutrons of $2.8 \times 10^{13} \mathrm{n} \mathrm{s}^{-1} \mathrm{~cm}^{-2}$ at $150^{\circ} \mathrm{C}$. After "cooling", the gamma-spectrometric measurements of the irradiated samples were conducted with a semiconductor $\mathrm{Ge}(\mathrm{Li})$ detector that was coupled to a 4096-channel high resolution pulse analyser LP-4900 ("Nokia", Finland). The elemental composition calculations of the irradiated samples were performed using statistical software that was developed ad hoc. This procedure confirmed that the precision (less than $4.6 \%$ for Co, less than $4 \%$ for Sc and less than $13 \%$ for $\mathrm{Zn}$ ) and accuracy of the determination of the concentration of the elements in the sediments were generally acceptable (Table 1). The detection limits were $0.05 \mathrm{mg} \mathrm{kg}^{-1}$ for $\mathrm{Co}$ and $\mathrm{Sc}$ and $10 \mathrm{mg} \mathrm{kg}^{-1}$ for $\mathrm{Zn}$. 
Fig. 2.- Vertical profiles of $\mathrm{Co} / \mathrm{Sc}$ ratios in cores SR1-SR5, SR10, SR22 and SR62 from the coastal zone of the Santa Rosalía mining region.

Fig. 2.- Perfiles verticales de las relaciones $\mathrm{Co} / \mathrm{Sc}$ en los testigos SR1SR5, SR10 y SR 62 de la zona costera de la región minera de Santa Rosalía.

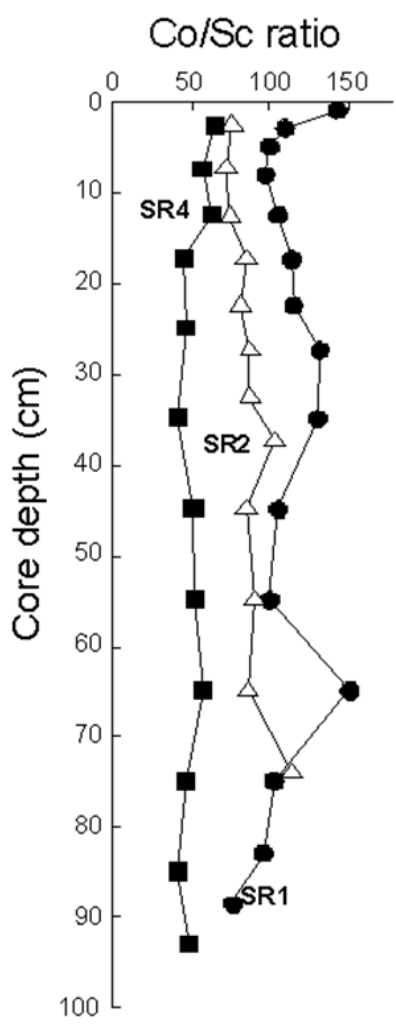

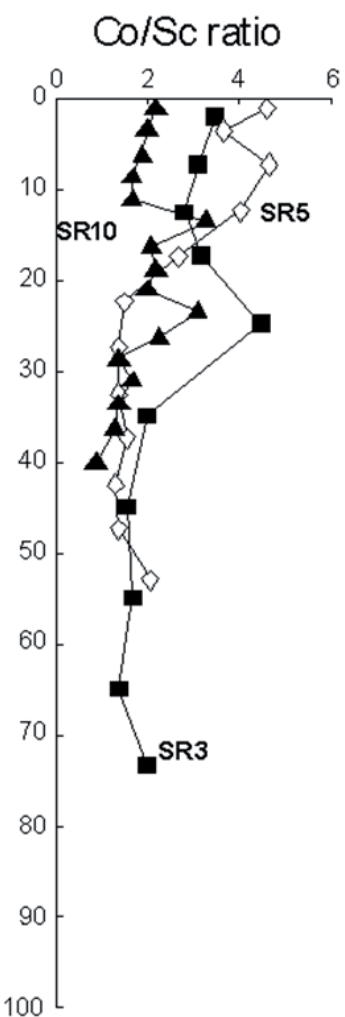

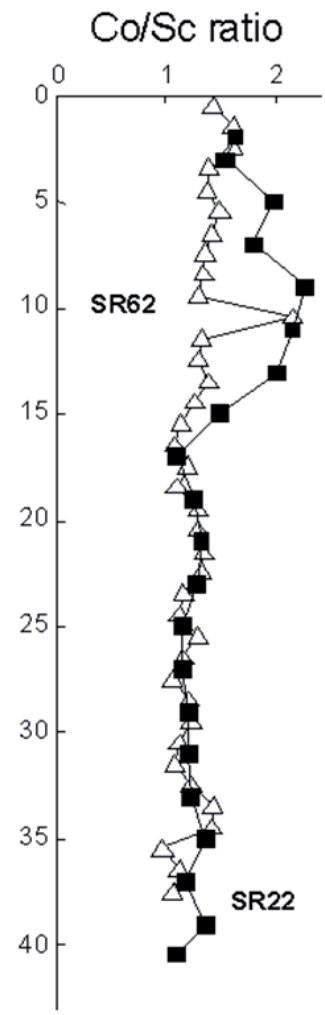

\begin{tabular}{|c|c|c|}
\hline $\begin{array}{l}\text { Sedimentary } \\
\text { material }\end{array}$ & $\mathrm{Co} / \mathrm{Sc}(\mathbf{n})^{\mathrm{s}}$ & $\mathrm{Zn} / \mathrm{Sc}(\mathbf{n})^{\mathrm{s}}$ \\
\hline Core SR1 & $\frac{112 \pm 20}{77-151}(15)$ & $\frac{276 \pm 51}{169-341}(15)$ \\
\hline Core SR2 & $\frac{87 \pm 12}{72-114}(12)$ & $\frac{258 \pm 52}{162-320}(12)$ \\
\hline Core SR3 & $\frac{2.6 \pm 1.0}{1.4-4.5}(10)$ & $\frac{10.1 \pm 8.5}{0.8-29.7}$ \\
\hline Core SR4 & $\frac{52 \pm 8}{42-65}(12)$ & $\frac{214 \pm 36}{156-260}(12)$ \\
\hline Core SR5 & $\frac{2.5 \pm 1.4}{1.3-4.7}(12)$ & $\frac{8.9 \pm 7.3}{0.7-23.0}$ \\
\hline Core SR10 & $\frac{1.9 \pm 0.6}{0.9-3.3}(16)$ & $\frac{9.4 \pm 7.3(16)}{0.6-30.9} \frac{(8.0 \pm 4.7)(15)}{(0.6-20.7)^{s}}$ \\
\hline Core SR22* & $\frac{1.4 \pm 0.4(21)}{0.4-2.3}$ & $\frac{15.2 \pm 5.4(21)}{5.5-25.0}$ \\
\hline Core SR62** & $\frac{1.3 \pm 0.2(38)}{1.0-2.1}$ & $\frac{16.6 \pm 3.4(38)}{6.8-23.9}$ \\
\hline $\begin{array}{l}\text { Surficial sediments, } \\
\text { northern margin** }\end{array}$ & $\frac{1.0 \pm 0.4(18)}{0.4-2.5}$ & $\frac{8.2 \pm 4.9(18)}{3.5-24.7}$ \\
\hline $\begin{array}{l}\text { Surficial sediments, } \\
\text { southern margin*** }\end{array}$ & $\frac{1.7 \pm 0.7(20)}{0.9-3.8}$ & $\frac{11.5 \pm 7.4(20)}{2.1-22.7}$ \\
\hline
\end{tabular}

${ }^{\$} \mathrm{Co} / \mathrm{Sc}$ and $\mathrm{Zn} / \mathrm{Sc}$ ratios were tested for discordant outliers using the computer program DODESSYS (Verma and Díaz-González, 2012) under the option of all singleoutlier tests and new precise critical values by Verma et al. (2008) before computing the mean and standard deviation values. Only for one core (SR10) one discordant outlier was detected. Average \pm S.D (number of observations $=n$ ); range is reported in the second row.

* Shumilin et al. (2000a); ** Choumiline et al. (2006)

Table 3.- $\mathrm{Co} / \mathrm{Sc}$ and $\mathrm{Zn} / \mathrm{Sc}$ ratios for the sediment cores and surface sediments of northern and southern margins off the Santa Rosalía mining region

Tabla 3.- Relaciones $\mathrm{Co} / \mathrm{Sc}$ y $\mathrm{Zn} / \mathrm{Sc}$ para los sedimentos de los testigos y los sedimentos superficiales de los márgenes norte y sur al frente de la región minera de Santa Rosalía

\section{Results}

The concentrations of $\mathrm{Co}, \mathrm{Sc}$ and $\mathrm{Zn}$ that were measured in the sediments of the coastal cores SR1-SR4 and SR10 are given in Table 2.

The concentrations of $\mathrm{Co}$ and $\mathrm{Zn}$ that were heavily influenced by the Santa Rosalía copper smelter were very high in cores SR1, SR2 and SR3. The levels of Co and Zn were lower in cores SR4 and SR5 in core SR10, which was collected north of the principal pollution "hot spot" of Santa Rosalía (Shumilin et al., 2000 b; Choumiline et al., 2006; Rodríguez Figueroa, 2010).

If we apply the sediment quality guidelines that were proposed by Long et al. (1995) for Zn (Effect Range Low $(E R L)=150 \mathrm{mg} \mathrm{kg}^{-1}$ and Effect Range Medium (ERM) $\left.=410 \mathrm{mg} \mathrm{kg}^{-1}\right)$, the concentrations of $\mathrm{Zn}$ in all of the sediment depths in cores SR1, SR2 and SR4 were much higher than its ERM sediment quality guideline values, indicating potential risks for the marine biota. The $\mathrm{Zn}$ concentrations in the upper $20 \mathrm{~cm}$ of the SR 3 core and in the upper $13 \mathrm{~cm}$ of the SR5 core were lower than its ERM sediment quality guidelines values but were still higher than the ERL guidelines values. However, below these sediment depths, the concentrations of $\mathrm{Zn}$ ostensibly would not represent any ecological risk. The sediment core SR10 from the northern margin that was collected in front of the El Boleo arroyo displayed $\mathrm{Zn}$ concentrations that were equal or slightly higher than the ERL guide- 



Fig. 3.- Vertical profiles of $\mathrm{Zn} / \mathrm{Sc}$ ratios in cores SR1SR5, SR10, SR22 and SR62 from the coastal zone of the Santa Rosalía mining region.

Fig. 3.- Perfiles verticales de las relaciones $\mathrm{Zn} / \mathrm{Sc}$ en los testigos SR1-SR5, SR10, SR22 y SR 62 de la zona costera de la región minera de Santa Rosalía. line sediment quality value at certain layers of the core $(7.5-10 \mathrm{~cm}, 12.5-15 \mathrm{~cm}, 17.5-20 \mathrm{~cm}$ and $22.5-25 \mathrm{~cm})$, but the $\mathrm{Zn}$ concentrations were generally lower than the ERL guideline values.

\section{Discussion}

The grain size of the coastal sediments from Santa Rosalía mining region is very heterogeneous due to its specific lithology and the occurrence of anthropogenic solid waste dumping (Rodríguez Figueroa, 2010). Generally, mixtures of particles of different sizes and origins are observed on spatial and temporal scales (Rodríguez Figueroa, 2010). To minimise possible effects of grain size variability and dilution of the contaminants in the sediments by inert quartz, by biogenic calcium carbonate or silica, the concentrations of $\mathrm{Co}$ and $\mathrm{Zn}$ were normalised with Sc. The regional background levels of the $\mathrm{Co} / \mathrm{Sc}$ and $\mathrm{Zn} / \mathrm{Sc}$ ratios in the study area and the shapes of the $\mathrm{Co} / \mathrm{Sc}$ and $\mathrm{Zn} / \mathrm{Sc}$ ratios vertical profiles were useful to evaluate the depth of penetration of tailing and smelting solid waste particles into the coastal marine sediments.

General information about the values of the $\mathrm{Co} / \mathrm{Sc}$ and $\mathrm{Zn} / \mathrm{Sc}$ ratios in the coastal and deep marine sediments in front of the Santa Rosalía mining region is presented in Table 3. The vertical profiles of $\mathrm{Co} / \mathrm{Sc}$ and $\mathrm{Zn} / \mathrm{Sc}$ ratios in the sediment cores of this study (cores SR1-5, SR10) as well as SR22 (from Shumilin et al., 2000a) and SR62 (from Choumiline et al., 2006) are shown in Figures 2 and 3 .

As shown in Table 3, high mean values of $\mathrm{Co} / \mathrm{Sc}$ ratio that ranged from 52 to 106 were detected for cores SR1, SR2 and SR4, and they were much lower for cores SR3, SR5 and SR10 (a range of 1.9-2.9). The lowest, most likely background, values were found in cores SR22 and SR62, where they ranged from 1.11 to 1.26 . The highest $\mathrm{Zn} / \mathrm{Sc}$ ratios were also found in SR1, SR2 and SR4 cores (a range of 214-262), followed by the open-sea core SR62 (a range of 11.7-24.1) and then cores SR3, SR5 and SR10 (a range of 8.9-10.1).

The observed $\mathrm{Co} / \mathrm{Sc}$ ratios in the lower depths of cores SR3, SR5, SR10 and SR22 most likely corresponded to the local background conditions. Surface coastal sediments outside the study area showed slightly higher values of $\mathrm{Co} / \mathrm{Sc}$ ratio that ranged from 1.6 to 6.0 (mean $3.4 \pm 1.2$ ) along the northern margin and from 0.9 to 8.7 (mean 3.8 \pm 1.8 ) along the southern margin, supposedly reflecting the shore littoral transport of the contaminants from the highly polluted areas located near the town of Santa Rosalía.

The shape of the vertical profile $\mathrm{Co} / \mathrm{Sc}$ ratio of SR22 sediment core (depth $360 \mathrm{~m}$ ) in front of the main pollution "hot spot" showed that the maximum levels of pollution occurred in the past (see increased $\mathrm{Co} / \mathrm{Sc}$ ratio values for samples collected from about $5-15 \mathrm{~cm}$ subsurface depth interval in Fig. 2), and self-purification/restoration of the natural pollutant levels in the fine grained deep- 
water sediments has occurred during recent years (see decreasing $\mathrm{Co} / \mathrm{Sc}$ values for samples collected from about $<5 \mathrm{~cm}$ depth in Figure 2).

The $\mathrm{Zn} / \mathrm{Sc}$ ratios of the surficial sediments from the northern and southern margin did not exhibit the same tendency for the $\mathrm{Co} / \mathrm{Sc}$ ratios as for the $\mathrm{Zn} / \mathrm{Sc}$ ratios as was the case for the deeper cores SR22 and SR62. This situation could be due to the lower influence of contamination of the deep sediments in the central portion and slightly elevated contributions of accumulated biogenic particulate $\mathrm{Zn}$ from the water column in cores SR22 and SR62.

Cobalt is not a typical contaminant found in the coastal marine sedimentary environment, as it predominantly appears at background levels (Cobelo-García and Prego, 2003). Being mainly of terrigenous origin in coastal sediments, it is usually incorporated into natural resistant aluminosilicate matrices of marine sediments, and for that reason, cobalt was proposed as an additional terrigenous indicator or normaliser to identify the anthropogenic impacts of $\mathrm{Cu}, \mathrm{Pb}$ and $\mathrm{Zn}$ on coastal marine sediments from the continental margin adjacent to Sydney, Australia (Matthai and Birch, 2001). However, certain levels of non-detrital Co in surface sediments from the Bay of Bengal have previously been attributed to anthropogenic contamination (Selvaraj et al., 2004). In contrast, marine sediments formed in the areas of high biological productivity and driven by coastal upwellings are often depleted in Co due to the remobilisation of this element from particles in oxygen-depleted water and sedimentary environments (Brumsack, 2006).

Somewhat higher $\mathrm{Zn} / \mathrm{Sc}$ ratio values in open-sea sediment cores (Shumilin et al., 2000a; Choumiline et al., 2006) relative to coastal "background" cores are most likely a result of the bioaccumulation of $\mathrm{Zn}$ in plankton organisms with the subsequent inclusion of their debris into the sea floor sediments. Additionally, it is hard to say to what extent the nearby Guaymas Basin with its hydrothermal sources influences the $\mathrm{Zn}$ concentrations, as direct observations over a hydrothermal area have previously indicated elevated levels of dissolved and particulate $\mathrm{Zn}$ no higher than $600 \mathrm{~m}$ above a $2000 \mathrm{~m}$ deep sea floor (Tambiev and Demina, 1992).

\section{Conclusions}

The ratios of $\mathrm{Co} / \mathrm{Sc}$ and $\mathrm{Zn} / \mathrm{Sc}$ in cores from the predominant pollution "hot spot" near Santa Rosalía port were very high (40-150 and 150-350, respectively). The values of $\mathrm{Co} / \mathrm{Sc}$ and $\mathrm{Zn} / \mathrm{Sc}$ ratios decreased drastically in the cores that were collected outside the main "hot spot" below a core depth of 20-34 cm and approached the regional coastal surface sediment background ratios (approximately 2 and 5-10 for $\mathrm{Co} / \mathrm{Sc}$ and $\mathrm{Zn} / \mathrm{Sc}$, respec- tively).

The $\mathrm{Co} / \mathrm{Sc}$ ratios for the sediments of the deeper cores were slightly variable, but they were nearly constant and were approximately equal to the $\mathrm{Co} / \mathrm{Sc}$ ratio of the earth's crust at sediment depths below $15 \mathrm{~cm}$. The $\mathrm{Zn} / \mathrm{Sc}$ ratios in the same cores were higher (10-20) than the $\mathrm{Zn} / \mathrm{Sc}$ ratio of the earth's crust, which was probably due to the additional input of incompletely mineralised biogenic particulate $\mathrm{Zn}$ from the photic zone of the water column. $\mathrm{Co} /$ Sc ratios along core SR22 showed that the maximum levels of pollution occurred in the past, and self-purification/ restoration of the natural pollutant levels in the fine deepwater sediments has occurred during recent years.

\section{Acknowledgments}

This study was supported by a grant (SEMARNAT2002-C01-1425) from the Secretaría de Medio Ambiente y Recursos Naturales and Consejo Nacional de Ciencia y Tecnología of Mexico, in addition to funding from projects \#20060906 and \#20113395 from the Secretaría de Posgrado e Investigación of the Instituto Politécnico Nacional of Mexico. We are also most grateful to two reviewers (Dr. Vladimir M. Shulkin and Dr. Selvaraj Kandasamy) whose critical comments on an earlier version of our manuscript helped us to improve our presentation.

\section{References}

Brumsack, H.J. (2006): The trace metal content of recent organic carbon-rich sediments: Implication for Cretaceous black shale formation. Palaeogeography, Palaeoclimatology, Palaeoecology 232, 344-361. doi: 10.1016/j.palaeo.2005.05.011

Choumiline, E., Méndez Rodríguez, L., Morton Bermea, O., Rodríguez Meza, G., Rodríguez Figueroa, G., Sánchez Rodríguez, I., Vargas Acosta, B. (2006): Evaluación biogeoquímica de los metales pesados en el ambiente marino del distrito minero de Santa Rosalía, B.C.S Informe técnico final del proyecto 2002-C01-1425 de SEMARNATCONACYT (2003-2006).

Cobelo-García, A., Prego, R. (2003): Heavy metal sedimentary record in a Galician Ria (NW Spain): background values and recent contamination. Marine Pollution Buletin 46, 1253-1262. doi: 10.1016/ S0025-326X(03)00168-1

Dias, M.I., Prudêncio, M.I. (1998): On the importance of using scandium to normalize geochemical data preceding multivariate analyses applied to archaeometric pottery studies. Microchemical Journal 88 , 136-141. doi: 10.1016/j.microc.2007.11.009

Elberling, B., Asmund, G., Kunzendorf, H., Krogstad, E.J. (2002): Geochemical trends in metal-contaminated fjord sediments near a former lead-zinc mine in West Greenland. Applied Geochemistry 17, 493 502. doi: 10.1016/S0883-2927(01)00119-6

Ergin, M., Kazan, B., Ediger, B. (1996): Source and depositional controls of heavy metal distribution in marine sediments of the Gulf of Iskenderun, Eastern Mediterranean. Marine Geology 133, 223-239. doi: 10.1016/0025-3227(96)00011-4

Grousset, F.E., Quetel, C.R., Thomas, B., Donard, O.F.X., Lambert, C.E., Guillard, F., Monaco, A. (1995): Anthropogenic vs. lithogenic origins of trace elements ( $\mathrm{As}, \mathrm{Cd}, \mathrm{Pb}, \mathrm{Rb}, \mathrm{Sb}, \mathrm{Sc}, \mathrm{Sn}, \mathrm{Zn}$ ) in water 
column particles: northwestern Mediterranean Sea. Marine Chemistry 48, 291-310. doi: 10.1016/0304-4203(94)00056-J

Hamilton, E.I. (1994): The geobiochemistry of cobalt. Science of Total Environment 150, 7-39. doi: 10.1016/0048-9697(94)90126-0

Matthai, C., Birch, G. (2001): Detection of anthropogenic $\mathrm{Cu}, \mathrm{Pb}$ and $\mathrm{Zn}$ in continental shelf sediments off Sydney, Australia-a new approach using normalization with cobalt. Marine Pollution Bulletin 42, 1055 1063. doi: 10.1016/S0025-326X(01)00068-6

Monna, F., Galop, D., Carozza, L., Tual, M., Beyrie, A., Marembert, F., Chateau, C., Dominik, J., Grousset, F.E. (2004): Environmental impact of early Basque mining and smelting recorded in a high ash minerogenic peat deposit. Science of Total Environment 327, 197214. doi:_10.1016/j.scitotenv.2004.01.010

Rodríguez Figueroa, G. (2004): Geoquímica de los oligoelementos, elementos mayores y elementos de las tierras raras, en los sedimentos marinos del distrito minero de Santa Rosalia, B.C.S., México. M.S. Thesis. Centro Interdisciplinario de Ciencias Marinas-Instituto Politécnico Nacional, La Paz, México. 137p.

Rodríguez Figueroa, G.M. (2010): Niveles de contaminación por metales pesadosen la zona costera de Santa Rosalia: sedimentos y macroalgas. PhD Thesis. Centro Interdisciplinario de Ciencias Marinas. Instituto Politécnico Nacional, La Paz, Baja California Sur, México. $177 \mathrm{p}$.

Rodríguez Figueroa, G., Shumilin, E., Páez-Osuna, F., Nava-Sánchez, E., Sapozhnikov, D. (1998): Ocurrencia de metales y metaloides en sedimentos superficiales de cuatro abanico-deltas de la costa oriental de Baja California Sur. Actas INAGEQ 4, 43-50.

Rodríguez-Figueroa, G., Shumilin, E., Sánchez-Rodríguez, I. (2009): Heavy metal pollution monitoring using brown seaweed Padina Durviaelli in the coastal zone of Santa Rosalía mining region, Peninsula of Baja California. Journal of Applied Phycology 21, 19-26. doi: 10.1007/s10811-008-9346-0

Selvaraj, K., Ram Mohan, V., Szefer, P. (2004): Evaluation of metal contamination in coastal sediments of the Bay of Bengal, India: geochemical and statistical approaches. Marine Pollution Bulletin 49, 174-185. doi: 10.1016/j.marpolbul.2004.02.006

Shulkin, V.M. (1998): Pollution of the coastal bottom sediments at the Middle Primorie (Russia) due to mining activity. Environmental Pollution 101, 401-404. doi: 10.1016/S0269-7491(98)00031-1

Shumilin, E., Kalmykov, St., Sapozhnikov, D., Nava-Sánchez, E., Gorsline, D., Godínez- Orta, L., Sapozhnikov, Yu., Holguin-Quiñónez, O., Rodríguez-Castañeda, A. (2000a): Major and trace element accumulation in coastal sediments along southeastern Baja California studied by instrumental neutron activation analysis and ${ }^{210} \mathrm{~Pb}$ age-dating. Journal of Radioanalytical and Nuclear Chemistry 246, 533-541. doi: 10.1023/A:1006728604262

Shumilin, E., Rodríguez-Figueroa, G., Morton Bermea, O., Lounejeva Baturina, E., Hernández, E., Rodríguez Meza, G.D. (2000b): Anomalous trace element composition of coastal sediments near the copper mining district of Santa Rosalía, Peninsula of Baja California, Mexico. Bulletin of Environmental Contamination and Toxicology 65, 261268. doi: $10.1007 / \mathrm{s} 001280000123$

Shumilin, E., Rodríguez-Figueroa, G., Sapozhnikov, D. (2005): Lanthanide contamination and strong europium positive anomaly in the surface sediments of the Santa Rosalía copper mining region, Baja California peninsula, Mexico. Bulletin of Environmental Contamination and Toxicology 75, 308-315. doi: 10.1007/s00128-005-0754-4

Shumilin, E., Gordeev, V., Rodriguez Figueroa, G., Demina, L., Choumilin, K. (2011): Assessment of geochemical mobility of metals in surface sediments of the Santa Rosalía mining region, western Gulf of California. Archives of Environmental Contamination and Toxicology 60, 8-25. doi: 10.1007/s00244-010-9532-3

Smith, I.C., Carson, B.L. (1981): Trace metals in the environment. Volume 6. Cobalt. Ann Arbor Science Publishers, Ann Arbor, MI. 1202p.

Sunda, W., Huntsman, S. (1995): Cobalt and zinc inter-replacement in marine phytoplankton. Limnology and Oceanography 40, 1404-1417.

Tambiev, S.B., Demina, L.L. (1992): Biogeochemistry and fluxes of manganese and some other metals in regions of hydrothermal activities (Axial Mountain, Juan de Fuca Ridge and Guaymas Basin, Gulf of California). Deep-Sea Research 39, 687-703.

Tovar-Sánchez, A., Sañudo-Wilhelmy, S., Russel Flegal, A. (2004): Temporal and spatial variations in the biogeochemical cycling of cobalt in two urban estuaries: Hudson River Estuary and San Francisco Bay. Estuarine, Coastal and Shelf Science 60, 717-728. doi: 10.1016/j.ecss.2004.03.010

Verma, S.P., Díaz-González, L. (2012): Application of the discordant outlier detection and separation system in the geosciences: International Geology Review 54, 593-614. doi: 10.1080/00206814.2011.569402

Verma, S.P., Quiroz-Ruiz, A., Díaz-González, L. (2008): Critical values for 33 discordancy test variants for outliers in normal samples up to sizes 1000, and applications in quality control in Earth Sciences. Revista Mexicana de Ciencias Geológicas 25, 82-96.

Wilson, I.F., Rocha, V.S. (1955): Geology and mineral deposits of the El Boleo copper district, Baja California, Mexico. Geological Survey Professional Paper 273. US Government Printing Office, Washington. $134 \mathrm{p}$. 